\title{
Pengaruh program motor cognitive coordination training terhadap gross motor skill dan working memory dalam pendidikan jasmani
}

\section{Lili Setiawan*, Yudy Hendrayana \& Agus Mahendra}

Universitas Pendidikan Indonesia

Jl. Dr. Setiabudhi No.229, Cidadap, Isola, Sukasari, Isola, Kec. Sukasari, Kota Bandung, Jawa Barat 40154

*Corresponding Author. e-mail: lilisetiawan19@gmail.com

\begin{abstract}
Abstrak
Motor cognitive coordination training merupakan sebuah konsep latihan multimodel yang mengkombinasikan aktivitas fisik dengan stimulasi kognitif. Tujuan utama dari penelitian ini adalah untuk mengetahui pengaruh motor cognitive coordination training terhadap gross motor skill dan working memory dalam pendidikan jasmani di sekolah dasar. Sampel dalam penelitian ini adalah siswa SD Negeri Leles I (kelompok control) dan SD Negeri Leles III (kelompok treatment) yang terlibat aktif dalam aktivitas pembelajaran akademis pada anak usia 9-10 tahun. Metode yang digunakan dalam penelatian ini adalah the matching only-pretest-posttest control group design. Instrumen yang digunakan yaitu test gross motor development (TGMD-3) untuk mengukur 13 keterampilan motorik mendasar, dibagi lagi menjadi dua sub-skala yaitu Keterampilan Lokomotor dan Object Control. Sedangkan Digit Span Test untuk mengukur daya ingat (working memory). Hasil penelitian menunjukan bahwa pengaruh motor cognitive coordination training dalam program aktivitas pendidikan jasmani lebih baik dibandingkan program aktivitas pendidikan jasmani terhadap peningkatan gross motor skill dan working memory siswa di sekolah dasar. Penelitian ini mengungkapkan program gerak yang dapat meningkatkan kemampuan kognitif dan motorik anak, salah satunya dengan menerapkan program motor cognitive coordination training.
\end{abstract}

Kata Kunci: aktivitas fisik, kognitif, gross motor skill, working memory

\section{The influence of motor cognitive coordination training program on gross motor skill and working memory of physical education}

\begin{abstract}
Motor cognitive coordination training is a multimodel exercise concept that combines physical activity with cognitive stimulation. The purpose of this study is to find out whether there is an influence from the motor cognitive coordination training program on gross motor skill and working memory of physical education in elementary school. The sample in this study were students of Leles I Elementary School (control group) and Leles III Elementary School (treatment group) who were actively involved in academic learning activities in children aged 9-10 years. This research uses the matching only-pretestposttest control group design as a method and uses of instrument like test gross motor development (TGMD-3) to measure 13 basic motor skills, subdivided into two subscales namely Locomotor Skills and Object Control. While Digit Span Test to measure memory (working memory). The results showed the effect of motor coordination on cognitive training in physical education activity programs is better than physical education activity programs against increasing gross motor skills and working memory of students in elementary school. This research explains the important of program which can increase cognitive and motoric skill of students, like apply motor cognitive coordination program.
\end{abstract}

Keywords: physical activity, cognitive, gross motor skill, working memory

How to Cite: Setiawan, L., Hendrayana, Y., \& Mahendra, A. (2020). Pengaruh program motor cognitive coordination training terhadap gross motor skill dan working memory dalam pendidikan. Jurnal Penelitian Ilmu Pendidikan, 13(2), 94-109. doi: https://doi.org/10.21831/jpipfip.v13i2.29279

Received 12-02-2020; Received in revised from 12-03-2020; Accepted 03-08-2020 
Jurnal Penelitian Ilmu Pendidikan, 13 (2), 2020 - 95

Setiawan, Hendrayana \& Mahendra

\section{PENDAHULUAN}

Motor cognitive coordination training merupakan sebuah metode latihan yang berkembang berdasarkan metode latihan life kinetik (Horst Lutz, 2014). Latihan life kinetik ialah sebuah konsep latihan yang melibatkan pengendalian adaptasi tubuh, kemampuan persepsi sensorik dan efektifitas kemampuan kognitif dalam keterampilan sederhana seperti koordinasi atau keseimbangan mata-tangan yang dikombinasikan dengan tugas intelektual untuk membuat latihan yang kompleks (Lutz, 2017).

Sedangkan menurut Johann, Stenger, Kersten, \& Karbach (2016) mengatakan motor cognitive coordination training itu sendiri adalah metode latihan psikologis modern yang sangat berkembang dan populer di Eropa Barat. Hasil latihan motor cognitive coordination training dipandang penting untuk meningkatkan kemampuan koordinasi dan fungsi kognitif (Lauenroth, Ioannidis, \& Teichmann, 2016). Dua tahun terkahir sebuah studi menyatakan metode motor cognitive coordination training memberikan pengaruh signifikan terhadap kemampuan kognitif pada anak di sekolah dasar (Pietsch, Böttcher, \& Jansen, 2017). Studi lain mengungkapkan motor cognitive coordination training memberikan pengaruh positif terhadap kemampuan kognitif dan perkembangan motorik pada anak (Luz, Rodrigues, \& Cordovil, 2015; dan Elferink-gemser, Smith, \& Visscher, 2014).

Berdasarkan beberapa hasil penelitian di atas, menunjukkan bahwa motor cognitive coordination training memberikan keuntungan terhadap peningkatan kognitif yang lebih besar. Integrasi tugas kognitif ke dalam aktivitas fisik lebih memberikan pengaruh signifikan terhadap peningkatkan pembelajaran kognitif pada anak, daripada aktivitas fisik yang tidak terintegrasi dengan tugas kognitif (Mavilidi, Okely, Chandler, Domazet, \& Paas, 2018). Herold, Hamacher, Schega, \& Müller, (2018) berpendapat bahwa motor cognitive coordination training lebih bermanfaat dalam hal menstabilkan kemampuan sistem saraf otak untuk beradaptasi dan memodifikasi organisasi secara struktural, fungsional terhadap stimulasi yang berlangsung sesuai dengan kebutuhannya (neuroplastisitas) yang secara khusus mempengaruhi kinerja motorik dan kognitif (Plummer \& Eskes, 2015). Studi penelitian telah melaporkan bahwa kemampuan kognitif meliputi memori (Verhaeghen, Marcoen, \& Goossens, 1992; Rebok, Carlson, \& Langbaum, 2007; dan Boron, Turiano, Willis, \& Schaie, 2007), working memory (Brehmer, Westerberg, \& Bäckman, 2012; Smith, Li, Schmiedek, Huxhold, \& Ro, 2008), atensi dan kecepatan pemrosesan (Roenker et al., 2003; Edwards, Wadley, Vance, Wood, \& Roenker, 2005), serta kontrol eksekutif (Bherer et al., 2005).

Fungsi kognitif pada manusia memiliki peranan masing-masing. Salah satunya working memory yaitu sebagai sebuah tempat penyimpanan aktif yang digunakan untuk menyimpan dan memanipulasi informasi (Baddeley, 2003). Working memory berkembang dari waktu ke waktu, karena kapasitas working memory yang ada pada anak-anak, remaja, dan orang dewasa pasti akan berbeda karena dipengaruhi oleh berbagai faktor. Adams, Nguyen, \& Cowan (2018) mendeskripsikan working memory sebagai sejumlah informasi terbatas yang dapat dipertahankan sementara, serta diakses dalam keadaan tertentu, sehingga berguna untuk banyak tugas kognitif. Working memory adalah bagian memori yang menjadi tempat penyimpanan informasi yang pada saat itu sedang dipikirkan. Pemikiran yang kita sadari dan dimiliki pada saat tertentu disimpan kedalam memori jangka pendek (Slavin, 2013). Dengan kata lain, working memory merupakan informasi yang tetap aktif dan mudah diakses, bisa digunakan pada tugas-tugas kognitif di dalam kecerdasan yang bervariasi (Cowan, 2016).

Fungsi working memory salah satunya terjadi dalam proses mengingat. Daya ingat merupakan hal yang sangat penting bagi setiap individu yang berperan dalam aktivitas sehari-hari termasuk proses belajar seperti kemampuan membaca dan kecepatan pemrosesan menerima informasi (Parisi et al., 2012). Para ahli juga berpendapat adanya peran working memory dalam semua proses kognitif misalnya dalam memahami bahasa, mengerjakan tugas pemecahan masalah dan juga tugas operasi Matematika (Smith et al., 2008). Maka dari itu perkembangan fungsi working memory pada anak sangat memerlukan perhatian, agar anak mampu berpikir cepat dalam menerima dan memanipulasi informasi yang diterima dari lingkungan sekitarnya.

Anak bukan hanya dituntut untuk mengembangkan fungsi kognitif, pengembangan kemampuan motorik juga sangat penting. Dari beberapa hasil penelitian disebutkan bahwa pengembangan kompetensi keterampilan gerak berkaitan dengan peningkatan aktivitas fisik, kebugaran, kardiorespirasi, prestasi akademik dan mengurangi prevalensi kelebihan berat badan dan obesitas (Robinson et al., 2015; Stodden et al., 2008; Vlahov, Baghurst, \& Mwavita, 2014; Jaakkola, Hillman, Kalaja, \& Liukkonen, 2015 dan O’ Brien, Belton, \& Issartel, 2016). 
Pada usia anak sekolah dasar memiliki kesempatan terbaik dalam mengembangkan keterampilan motorik karena pada anak usia dini terjadi pertumbuhan otak yang cepat serta pematangan neuromuscular bersamaan dengan tingkat kompetensi yang baik (Williams et al., 2012). Sebagaimana juga Hurlock (Hurlock, 1998) yang mengatakan bahwa perkembangan motorik merupakan perkembangan pengendalian gerakan jasmaniah melalui kegiatan pusat syaraf, urat syaraf dan otot terkoordinasi. Dengan memberikan kesempatan dan stimulasi yang tepat, anak dapat memiliki kemampuan perkembangan keterampilan gerak dasar yang optimal (Gallahue, 1995). Studi yang dilakukan oleh Veldman, Jones, \& Okely (2016) mengidentifikasi tujuh studi yang dikembangkan sebagai tanggapan terhadap data yang dikumpulkan dari 9 hingga 10 tahun, mengungkapkan rendahnya tingkat aktivitas fisik dan kebugaran, dan tingkat tinggi perilaku menetap dan obesitas (Boddy, Hackett, \& Stratton, 2009; Fairclough, Boddy, Hackett, \& Stratton, 2009 dan Stratton et al., 2007) menunjukkan kebutuhan untuk memulai intervensi pada anak usia dini. Intervensi tersebut melibatkan pengembangan profesional bagi pendidik (yaitu, guru dan asisten pengajar) agar mereka dapat memberikan pembelajaran aktivitas fisik yang sesuai perkembangan dalam lingkungan sekolah. Dengan demikian perkembangan motorik pada anak memerlukan perhatian, agar di masa yang akan datang performa yang dia miliki sesuai dengan apa yang diharapkan. Pada prinsipnya, para pakar psikologi sependapat bahwa pengalaman anak pada usia dini membawa akibat pada masa kehidupan yang akan datang.

Saat ini, anak-anak usia sekolah dihadapkan dengan banyak tantangan. Hidup di masa yang serba praktis dan canggih, di mana semuanya dapat dilakukan dengan cepat dan cenderung instan. Gaya hidup seperti ini membuat orang cenderung malas untuk bergerak. Hal ini akan memberikan dampak negatif pada kesehatan dan perkembangan anak. Misalnya saja ketika anak berangkat sekolah sampai pulang kembali ke rumah diantarkan menggunakan alat transportasi. Selain itu, dalam setiap aktivitas bermainnya anak hanya menghabiskan waktu dengan gadget, playstation, Xbox, Wii, PSP, game oneline, dan lain-lain yang cenderung mengajarkan anak hidup statis. Hal ini akan memberikan pengaruh negatif terhadap perkembangan pada setiap anak. Perlu diketahui bahwa periode perkembangan anak sangat penting, pada masa ini seluruh aspek perkembangan kecerdasan yaitu kecerdasan intelektual, emosi, gerak dan spiritual pada masa anak-anak mengalami perkembangan yang luar biasa sehingga akan mempengaruhi dan menentukan terhadap perkembangan selanjutnya. Oleh karena itu, guru sebagai tenaga professional perlu untuk mengembangkan strategi pembelajaran yang dapat memaksimalkan perkembangan anak seutuhnya.

Kemampuan kognitif dan motorik berkontribusi untuk menemukan solusi yang sesuai dalam bertindak secara fleksibel terhadap perubahan keadaan. Kemerosotan kemampuan kognitif pada siswa salah satunya disebabkan karena minimnya pembelajaran aktivitas jasmani yang dilakukan di sekolah (Niederer et al., 2011). Kegiatan pendidikan jasmani di sekolah sering dibatasi oleh beberapa alasan dan sering dianggap sebagai pelajaran yang mengganggu konsentrasi belajar. Padahal dengan pemberian aktivitas fisik pada anak sedini mungkin dapat memberikan manfaat yang baik terhadap fungsi kognitif mereka seumur hidup (Ratey \& Loehr, 2011). Tentunya ini menjadi tantangan bagi para stakeholder di bidang olahraga dan pendidikan jasmani khususnya guru pendidikan jasmani dalam merancang kegiatan atau model pembelajaran yang bermanfaat dan menarik sehingga pelajaran olahraga menjadi lebih bermakna. Tidak hanya sebagai sarana untuk berolahraga, aktif, bersenang dan istirahat sejenak dari mata pelajaran yang membuat stress. Olahraga atau pendidikan jasmani memiliki peran penting dalam menciptakan pribadi siswa yang sehat, cerdas dan dinamis.

Motor cognitive coordination training sekarang cukup diakui dari beberapa penelitian sebagai sebuah konsep latihan multimodel yang mengkombinasikan aktivitas fisik dengan stimulasi kognitif yang berpengaruh signifikan terhadap peningkatan fungsi kognitif dan melatih kemampuan motorik (Fritz, Cheek, \& Nichols-Larsen, 2015). Maka dari itu, peneliti bermaksud untuk meneliti hubungan positif antara motor cognitive coordination training terhadap fungsi kognitif serta meningkatkan kemampuan motorik. Sehingga tujuan dari penelitian adalah untuk mengetahui pengaruh dari motor cognitive coordination training terhadap gross motor skill dan working memory dalam pendidikan jasmani pada siswa sekolah dasar. 
Jurnal Penelitian Ilmu Pendidikan, 13 (2), 2020 - 97

Setiawan, Hendrayana \& Mahendra

\section{METODE}

Dalam penelitian ini populasi diambil yaitu seluruh siswa SD Negeri Leles I (kelompok kontrol) dan SD Negeri Leles III (kelompok eksperimen) yang terlibat aktif dalam aktivitas pembelajaran akademis pada anak usia 9-10 tahun.

Berdasarkan desain penelitian yaitu the matching only-pretest-posttest control group design sehingga dalam pengambilan sampel adalah teknik purposive sampling dilihat dari usia para sampel. Sehingga diperoleh sampel berusia 9-10 tahun dan harus menggunakan 20 orang sampel dari setiap kelompok maka jumlah total 40 orang berdasarkan sampel sedang menempuh pendidikan di sekolah dasar. Seperti dinyatakan oleh Fraenkel, Wallen \& Hyun (2011: 274) "provided there are at least 20 subjects in each group".

Metode yang digunakan untuk mencari jawaban dalam penelitian ini adalah dengan menggunakan metode eksperimen, yaitu metode untuk mencari pengaruh dari satu variabel bebas terhadap satu atau lebih variabel terikat. Variabel bebas dalam penelitian ini adalah motor cognitive coordination training dan variabel terikatnya adalah gross motor skill dan working memory. Desain digunakan dalam penelitian ini adalah Pretest-Posttest Control Group Design. Penggunaan desain tersebut disesuaikan dengan karakteristik penelitian serta pokok permasalahan dibahas dalam penelitian ini. Adapun gambaran mengenai desain tersebut dapat dilihat pada tabel 1.

Tabel 1. The Matching Only-Pretest-Posttest Control Group Design

\begin{tabular}{cccccc}
\hline Treatment Group & $\frac{\mathrm{M}}{\text { Control Group }_{n}}$ & $\frac{\mathrm{O}_{1}}{\mathrm{M}}$ & $\frac{\mathrm{X}}{\mathrm{O}_{1}}$ & $\mathrm{C}$ & $\frac{\mathrm{O}_{2}}{\mathrm{O}_{2}}$ \\
\hline
\end{tabular}

(Fraenkel, Wallen \& Hyun, 2011: 275)

Pada penelitian ini, kelompok eksperimen diberikan perlakukan aktivitas pendidikan jasmani yang ditambahkan program motor cognitive coordination training sedangkan kelompok kontrol diberikan aktivitas pendidikan jasmani. Hal ini bertujuan sebagai pembanding antara hasil kelompok kontrol dengan kelompok eksperimen.

Setiap pertemuan dilakukan 2 kali per minggu dengan waktu 20 menit pemberian motor cognitive coordination training, dan dilakukan selama 10 pertemuan. Ditambah dengan 2 pertemuan yaitu pelaksanaan pretest dan posttest, sehingga total pertemuan yang dilakukan adalah 12 pertemuan.

Test Gross Motor Development (TGMD-3) menilai 13 keterampilan motorik mendasar, dibagi lagi menjadi dua sub-skala: Keterampilan Lokomotor \& Object Control (Simons \& Eyitayo, 2016 \& Rintala, 2017). Tes ini mencakup tes gerak yang dikategorikan menjadi dua subvariabel yaitu Locomotor (Run, Gallop, Hop, Skip, Horizontal Jump, Slide) dan Object Control (Two-Hand Strike, One-Hand Strike, Dribble, Catch, Kick, Overhand Throw and Underhand Throw). Sedangkan digit span test digunakan untuk menilai kapasitas working memory anak. Untuk melakukan tes ini diperlukan sebuah lembar kerja yang memiliki deretan angka 3 sampai 8 digit atau 3 sampai 10 digit angka untuk forward dan 3 sampai 7 digit atau 3 sampai 9 digit deretan angka untuk backward (Kane et al., 2004).

Teknik analisis data meliputi mencari rata-rata, simpangan baku dan variansi, kemudian uji prasyarat analisis dan tahap terakhir uji hipotesis penelitian dengan bantuan aplikasi IBM SPSS satistics 20.

\section{HASIL DAN PEMBAHASAN}

\section{Hasil}

Pengolahan data untuk mencari rata-rata (mean), simpangan baku (standard deviation) dan varians (variance) dari perolehan skor gross motor skill dan working memory pada saat pre-test dan post-test pada kelompok eksperimen dan kelompok kontrol, merupakan langkah awal untuk pengujian selanjutnya. Adapun hasil pengolahan data gross motor skill pada tabel 2.

Berdasarkan pada tabel 2, dapat dikatakan bahwa untuk nilai rata-rata gross motor skill pada kelompok eksperimen mengalami peningkatan yang lebih signifikan dibandingkan dengan kelompok kontrol. 
Jurnal Penelitian Ilmu Pendidikan, 13 (2), 2020 - 98

Setiawan, Hendrayana \& Mahendra

Tabel 2. Perolehan Rata-rata Simpangan Baku dan Variance

\begin{tabular}{cclr} 
WM & Kelompok & \multicolumn{2}{c}{ Statistik } \\
\hline \multirow{4}{*}{ Pre-test } & \multirow{3}{*}{ Eksperimen } & Mean & 69.9000 \\
& & Variance & 3.147 \\
& & Std. Deviation & 1.77408 \\
& \multirow{2}{*}{ Kontrol } & Mean & 70.2500 \\
& & Variance & 3.250 \\
& & Std. Deviation & 1.80278 \\
Post-test & Mean & 79.3500 \\
& \multirow{2}{*}{ Eksperimen } & Variance & 4.555 \\
& & Std. Deviation & 2.13431 \\
& \multirow{2}{*}{ Kontrol } & Mean & 76.3000 \\
& & Variance & 9.168 \\
& & Std. Deviation & 3.02794 \\
\hline
\end{tabular}

Sebagaimana pada saat pre-test kelompok eksperimen diperoleh nilai rata-rata $(\pi=69,9)$ dan pada saat post-test diperoleh nilai rata-rata $(\pi=79,3)$ yang artinya mengalami peningkatan sebesar 9,45 . Sedangkan pada kelompok kontrol pada saat pre-test diperoleh nilai rata-rata $(\pi=70,25)$ dan pada saat post-test diperoleh nilai rata-rata $(\pi=76,3)$ yang artinya mengalami peningkatan sebesar 6,05 . Jika digambarkan ke dalam grafik diagram batang seperti gambar 1 berikut.

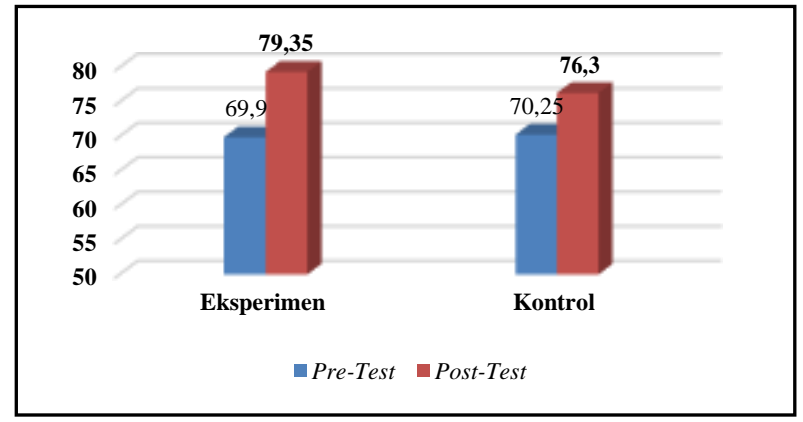

Gambar 1. Nilai gross motor skill

Sedangkan untuk hasil pengolahan data working memory terlihat pada tabel 3.

Tabel 3. Perolehan Rata-rata Simpangan Baku dan Variance

\begin{tabular}{cclr} 
WM & Kelompok & \multicolumn{2}{c}{ Statistik } \\
\hline \multirow{4}{*}{ Pre-test } & \multirow{3}{*}{ Eksperimen } & Mean & 69.0000 \\
& & Variance & 28.947 \\
& & Std. Deviation & 5.38028 \\
& \multirow{2}{*}{ Kontrol } & Mean & 68.5000 \\
& & Variance & 23.421 \\
& & Std. Deviation & 4.83953 \\
Post-test & Eean & 79.6000 \\
& \multirow{4}{*}{ Eksperimen } & Variance & 34.989 \\
& & Std. Deviation & 5.91519 \\
& \multirow{2}{*}{ Kontrol } & Mean & 730500 \\
& & Variance & 26.471 \\
& & Std. Deviation & 5.14500 \\
\hline
\end{tabular}


Berdasarkan pada tabel 3, dapat dikatakan bahwa untuk nilai rata-rata working memory pada kelompok eksperimen mengalami peningkatan yang lebih signifikan dibandingkan dengan kelompok kontrol. Sebagaimana pada saat pre-test kelompok eksperimen diperoleh nilai rata-rata $(\pi=69)$ dan pada saat post-test diperoleh nilai rata-rata $(\pi=79,6)$ yang artinya mengalami peningkatan sebesar 10,6 .

Sedangkan pada kelompok kontrol pada saat pre-test diperoleh nilai rata-rata $(\pi=68,5)$ dan pada saat post-test diperoleh nilai rata-rata $(\pi=73,05)$ yang artinya mengalami peningkatan sebesar 4,5. Adapun jika digambarkan ke dalam grafik diagram batang seperti gambar 2 berikut.

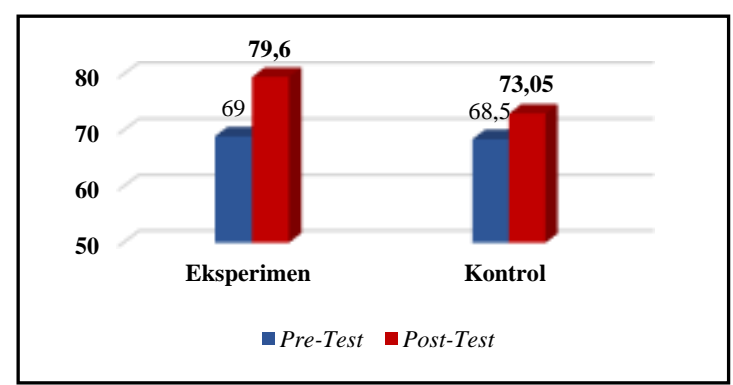

Gambar 2. Nilai working memory

Uji prasyarat analisis dilakukan untuk menguji hipotesis dengan beberapa prosedur yakni uji normalitas dan uji homogenitas data. Uji normalitas dilakukan pada data pre-test dan post-test pada kelompok eksperimen dan kelompok kontrol. Hal ini dilakukan untuk mengetahui apakah data berdistribusi normal atau tidak, sehingga penggunaan analisis statistik dapat ditentukan. Apakah menggunakan statistik parametrik (data normal) atau non-parametrik (data tidak normal). Selanjutnya uji homogenitas dilakukan terhadap data pre-test dan post-test pada kelompok eksperimen dan kelompok kontrol. Hal ini dilakukan untuk melihat apakah kelompok tersebut berasal dari variansi yang homogen sehingga kelompok tersebut bisa dibandingkan.

Uji normalitas ini digunakan untuk mengetahui apakah sampel penelitian ini berasal dari populasi yang berdistribusi normal atau tidak, pengujian normalitas (Test of normality) dilakukan dengan menggunakan uji shapiro-wilk pada taraf signifikansi $\alpha=0,05$. Adapun hasil dari uji normalitas (shapiro-wilk) untuk gross motor skill terdapat pada tabel 4.

Tabel 4. Uji Normalitas Data Gross Motor Skill

\begin{tabular}{rlrcrl}
\hline \multirow{2}{*}{ TGMD } & \multirow{2}{*}{ Kelompok } & \multicolumn{3}{c}{ Shapiro-Wilk } & \multirow{2}{*}{ Keterangan } \\
\cline { 3 - 5 } & & Statistic & df & Sig. & \\
\hline \multirow{2}{*}{ Pre-Test } & Eksperimen & .941 & 20 & .249 & Normal \\
& Kontrol & .912 & 20 & .070 & Normal \\
\multirow{3}{*}{ Post-Test } & Eksperimen & .936 & 20 & .197 & Normal \\
& Kontrol & .952 & 20 & .393 & Normal \\
\hline
\end{tabular}

Berdasarkan hasil uji normalitas pada tabel 3, dengan menggunakan uji shapiro-wilk diketahui data pre-test dan post-test, jika dibandingkan pada taraf nyata $(\alpha=0,05)$ menunjukan nilai signifikansi lebih besar dari $\alpha$ (sig. $>0,05)$ pada kelompok eksperimen dan kelompok kontrol.

Maka dapat disimpulkan bahwa data variabel gross motor skill pada kedua kelompok berdistribusi normal. Karena sesuai dengan kriteria pengambilan keputusan jika nilai sig. atau nilai probabilitas $\mathrm{P}>0,05$ (distribusi normal). Sedangkan untuk hasil uji normalitas (shapiro-wilk) untuk working memory terdapat pada tabel 5.

Berdasarkan hasil uji normalitas pada tabel 5 dengan menggunakan uji shapiro-wilk diketahui data pre-test dan post-test, jika dibandingkan pada taraf nyata $(\alpha=0,05)$ menunjukan nilai signifikansi lebih besar dari $\alpha$ (sig. $>0,05)$ pada kelompok eksperimen dan kelompok kontrol.

Maka dapat disimpulkan bahwa data variabel working memory pada kedua kelompok berdistribusi normal. Karena sesuai dengan kriteria pengambilan keputusan jika nilai sig. atau nilai probabilitas $\mathrm{P}>0,05$ (distribusi normal). 
Jurnal Penelitian Ilmu Pendidikan, 13 (2), 2020 - 100

Setiawan, Hendrayana \& Mahendra

Tabel 5. Uji Normalitas Data Working Memory

\begin{tabular}{clrrrl}
\hline \multirow{2}{*}{ W M } & \multirow{2}{*}{ Kelompok } & \multicolumn{3}{c}{ Shapiro-Wilk } & \multirow{2}{*}{ Keterangan } \\
\cline { 3 - 6 } & & Statistic & df & Sig. & \\
\hline \multirow{2}{*}{ Pre-Test } & Eksperimen & .917 & 20 & .088 & Normal \\
& Kontrol & .916 & 20 & .082 & Normal \\
& Eksperimen & .921 & 20 & .072 & Normal \\
\multirow{2}{*}{ Post-Test } & Kontrol & .913 & 20 & .072 & Normal \\
\hline
\end{tabular}

Setelah diketahui berdistribusi normal, selanjutnya adalah menguji homogenitas dua variansi dari masing-masing skor (gross motor skill dan working memory) pretest dan posttest kelompok eksperimen dan kelompok kontrol.

Uji homogenitas ini digunakan untuk mengetahui apakah sampel penelitian ini berasal dari populasi yang homogen atau tidak, pengujian kesamaan ragam (Homogenity of Variance) dengan menggunakan levene test. Adapun hasil dari uji homogenitas varians (Levene Test) untuk gross motor skill terdapat pada tabel 6.

Tabel 6. Uji Homogenitas Data Gross Motor Skill

\begin{tabular}{cccccc}
\hline TGMD & Levene Statistic & $d f 1$ & $d f 2$ & Sig. & Keterangan \\
\hline Pre-Test & .040 & 1 & 38 & .843 & Homogen \\
Post-Test & .855 & 1 & 38 & .361 & Homogen \\
\hline
\end{tabular}

Berdasarkan hasil uji homogenitas pada tabel 6 dengan menggunakan uji levene test diketahui bahwa data pre-test dan post-test, jika dibandingkan pada taraf nyata $(\alpha=0,05)$ menunjukan nilai signifikansi lebih besar dari $\alpha$ (sig.>0,05) pada kelompok eksperimen dan kelompok kontrol.

Maka dapat disimpulkan bahwa data variabel gross motor skill pada kedua kelompok variansi data adalah homogen. Karena sesuai dengan kriteria pengambilan keputusan jika nilai sig. atau nilai probabilitas $\mathrm{P}>0,05$, data berasal dari populasi memiliki varians sama (homogen). Sedangkan untuk hasil uji homogenitas (levene test) untuk working memory terdapat pada tabel 7.

Tabel 7. Uji Homogenitas Data Working Memory

\begin{tabular}{lccccc}
\hline W M & Levene Statistic & $d f 1$ & $d f 2$ & Sig. & Keterangan \\
\hline Pre-Test & .114 & 1 & 38 & .738 & Homogen \\
\hline Post-Test & .178 & 1 & 38 & .372 & Homogen \\
\hline
\end{tabular}

Berdasarkan hasil uji homogenitas pada tabel 6 dengan menggunakan uji levene test diketahui data pre-test dan post-test, jika dibandingkan pada taraf nyata $(\alpha=0,05)$ menunjukan nilai signifikansi lebih besar dari $\alpha$ (sig. $>0,05$ ) pada kelompok eksperimen dan kelompok kontrol.

Maka dapat disimpulkan bahwa data variabel working memory pada kedua kelompok variansi data adalah homogen. Karena sesuai dengan kriteria pengambilan keputusan jika nilai sig. atau nilai probabilitas $\mathrm{P}>0,05$, data berasal dari populasi memiliki varians sama (homogen).

Setelah data diasumsikan berdistribusi normal dan homogen dari masing-masing kelompok, maka langkah selanjutnya adalah pengujian hipotesis. Pendekatan statistik yang digunakan untuk pengujian hipotesis tersebut yaitu uji t (Paired sampel $t$ test). Uji t dilakukan untuk mengetahui perbandingan selisih dua mean dari sampel yang berpasangan yaitu nilai gross motor skill dan working memory dari data pre-test dan post-test pada kelompok eksperimen yang telah diberikan program motor cognitive coordination training. Adapun hasil uji t (Paired sampel t test) untuk mengetahui perbandingan selisih dua mean (pre-test dan post-test) variabel gross motor skill pada kelompok eksperimen, ditampilkan pada tabel 8. 
Jurnal Penelitian Ilmu Pendidikan, 13 (2), 2020 - 101

Setiawan, Hendrayana \& Mahendra

Tabel 8. Uji t (Paired sampel t test) Gross Motor Skill

\begin{tabular}{cccc}
\hline TGMD & $\mathrm{t}$ & $\mathrm{df}$ & Sig. (2-tailed) \\
\hline Pre-test-Post-test & 23.218 & 19 & .000 \\
\hline
\end{tabular}

Berdasarkan tabel 8, diperoleh nilai signifikansi (sig.) sebesar 0,000. Jika dibandingkan pada taraf nyata $(\alpha=0,05)$ menunjukan nilai signifikansi lebih kecil dari $\alpha(0,000<0,05)$ sesuai dengan kriteria pengambilan keputusan maka $H_{0}$ ditolak. Maka dapat disimpulkan bahwa terdapat pengaruh yang siginifikan dari motor cognitive coordination training terhadap peningkatan gross motor skill siswa dalam pendidikan jasmani di sekolah dasar. Sedangkan hasil uji t (Paired sampel t test) untuk mengetahui perbandingan selisih dua mean (pre-test dan post-test) variabel working memory pada kelompok eksperimen, sebagai tertera pada tabel 9.

Tabel 9. Uji t(Paired sampel t test) Working Memory

\begin{tabular}{cccc}
\hline Digit Span Test & $\mathrm{t}$ & $\mathrm{df}$ & Sig. (2-tailed) \\
\hline Pre-test-Post-test & 22.439 & 19 & .000 \\
\hline
\end{tabular}

Berdasarkan tabel 9, diperoleh nilai signifikansi (sig.) sebesar 0,000. Jika dibandingkan pada taraf nyata $(\alpha=0,05)$ menunjukan nilai signifikansi lebih kecil dari $\alpha(0,000<0,05)$ sesuai dengan kriteria pengambilan keputusan maka $H_{0}$ ditolak. Maka dapat disimpulkan bahwa terdapat pengaruh yang siginifikan dari motor cognitive coordination training terhadap peningkatan working memory siswa dalam pendidikan jasmani di sekolah dasar. Setelah dilakukan pengujian signifikasi dari kedua permainan, maka langkah selanjutnya adalah melihat signifikasi perbedaan dari peningkatan antara kelompok eksperimen dan kelompok kontrol yang sama-sama mengalami peningkatan yang signifikan. Adapun hasil perhitungan dan uji signifikasi kedua kelompok dapat dilihat pada tabel 10 untuk hasil perbedaan signifikansi gross motor skill.

Tabel 10. Uji t (Independent Sampel t test) Gross Motor Skill

\begin{tabular}{|c|c|c|c|c|c|}
\hline \multirow[b]{2}{*}{ Kelompok Sampel } & \multicolumn{2}{|c|}{ Gain } & \multirow[t]{3}{*}{$t_{\text {hitung }}$} & \multirow[t]{3}{*}{$\mathrm{t}_{\text {tabel }}$} & \multirow[t]{2}{*}{ Keterangan } \\
\hline & $\bar{x}$ & \multirow{2}{*}{$\begin{array}{l}\sqrt{s^{2}} \\
1,82\end{array}$} & & & \\
\hline Kelompok Eksperimen & 9,45 & & & & \\
\hline Kelompok Kontrol & 6,05 & 1,73 & 6,05 & 2,02 & Signifikan \\
\hline
\end{tabular}

Analisis yang digunakan adalah analisis nilai rata-rata peningkatan dari kedua kelompok. Secara sederhana prosedur analisis ini adalah membandingkan nilai rata-rata yang diperoleh dari motor cognitive coordination training dalam aktivitas program pendidikan jasmani dan aktivitas program pendidikan jasmani tanpa motor cognitive coordination training. Selisih antara post-test dengan pretest ini akan menunjukan kemajuan yang dialami siswa. Jika selisihnya berharga negatif, maka siswa tidak mengalami kemajuan bahkan mengalami kemunduran. Tetapi sebaliknya, jika selisihnya berharga positif maka peneliti mengambil kesimpulan bahwa siswa telah mengalami kemajuan.

Jika memperhatikan tabel 10 , diketahui selisih nilai dari motor cognitive coordination training dalam aktivitas program pendidikan jasmani didapat rata-rata 9,45 dengan simpangan baku 1,82, sedangkan nilai dari aktivitas program pendidikan jasmani tanpa motor cognitive coordination training didapat rata-rata 6,05 dengan simpangan baku 1,73. Hal ini menunjukan bahwa motor cognitive coordination training dalam aktivitas program pendidikan jasmani berpengaruh lebih baik terhadap peningkatan gross motor skill siswa di sekolah dasar. Setelah diolah dengan menggunakan uji $\mathrm{t}$ didapat $\mathrm{t}_{\text {hitung }} 6,05>\mathrm{t}_{\text {tabel }} 2,02$, artinya terdapat perbedaan pengaruh yang signifikan antara motor cognitive coordination training dalam aktivitas program pendidikan jasmani dan aktivitas program pendidikan jasmani tanpa motor cognitive coordination training terhadap peningkatan gross motor skill siswa di sekolah dasar.

Sedangkan hasil uji t (Independent sampel t test) untuk mengetahui perbandingan selisih dua rata-rata (kelompok eksperimen dan kelompok kontrol) variabel working memory, seperti terdapat 
Jurnal Penelitian Ilmu Pendidikan, 13 (2), 2020 - 102

Setiawan, Hendrayana \& Mahendra

pada tabel 11 .

Tabel 11. Uji t (Independent Sampel t test) Working Memory

\begin{tabular}{lccccl}
\hline \multicolumn{1}{c}{ Kelompok Sampel } & \multicolumn{2}{c}{ Gain } & $\mathrm{t}_{\text {hitung }}$ & $\mathrm{t}_{\text {tabel }}$ & Keterangan \\
& $\overline{\boldsymbol{x}}$ & $\sqrt{\boldsymbol{s}^{2}}$ & & & \\
\hline Kelompok Eksperimen & 10,6 & 2,11 & 10,3 & 2,02 & Signifikan \\
Kelompok Kontrol & 4,5 & 1,57 & & & \\
\hline
\end{tabular}

Analisis yang digunakan pada variabel working memory sama dengan variabel sebelumnya (gross motor skill) yaitu analisis nilai rata-rata peningkatan dari kedua kelompok. Secara sederhana prosedur analisis ini adalah membandingkan nilai rata-rata yang diperoleh dari motor cognitive coordination training dalam aktivitas program pendidikan jasmani dan aktivitas program pendidikan jasmani tanpa motor cognitive coordination training. Selisih antara post-test dengan pre-test ini akan menunjukan kemajuan yang dialami siswa. Jika selisihnya berharga negatif, maka siswa tidak mengalami kemajuan bahkan mengalami kemunduran. Tetapi sebaliknya, jika selisihnya berharga positif maka peneliti mengambil kesimpulan bahwa siswa telah mengalami kemajuan.

Berdasarkan pada tabel 11, diketahui selisih nilai dari motor cognitive coordination training dalam aktivitas program pendidikan jasmani didapat rata-rata 10,6 dengan simpangan baku 2,11. Sedangkan nilai dari aktivitas program pendidikan jasmani tanpa motor cognitive coordination training didapat rata-rata 4,5 dengan simpangan baku 1,57, Artinya pada variabel working memory juga menunjukan bahwa motor cognitive coordination training dalam aktivitas program pendidikan jasmani berpengaruh lebih baik terhadap peningkatan cognitive skill siswa di sekolah dasar. Serta berdasarkan hasil penghitungan uji $\mathrm{t}$ didapat $\mathrm{t}_{\text {hitung }} 10,3>\mathrm{t}_{\text {tabel }} 2,02$, artinya terdapat perbedaan pengaruh yang signifikan antara motor cognitive coordination training dalam aktivitas program pendidikan jasmani dan aktivitas program pendidikan jasmani tanpa motor cognitive coordination training terhadap peningkatan working memory siswa di sekolah dasar.

\section{Pembahasan}

Hasil temuan pada data penelitian menunjukan bahwa kelompok eksperimen memberikan peningkatan yang lebih tinggi sebagaimana ditampilkan pada gambar 1 . Hal tersebut juga dibuktikan dengan perhitungan pada masing-masing kelompok dalam pengembangan gross motor skill dan working memory daripada kelompok kontrol. Kedua kelompok penelitian yang dimaksud yaitu kelompok eksperimen (aktivitas pendidikan jasmani yang di dalamnya ditambahkan program motor cognitive coordination training) dan kelompok kontrol (aktivitas pendidikan jasmani yang tanpa program motor cognitive coordination training). Berdasarkan hasil tersebut, dapat disimpulkan bahwa meskipun antara kelompok eksperimen dan kelompok kontrol terlihat memiliki persamaan dengan diterapkannya aktivitas pendidikan jasmani, namun ada perbedaan yang signifikan pada kelompok eksperimen yaitu lebih besar peningkatan gross motor skill dan working memory ketika program motor cognitive coordination training diterapkan dalam aktivitas pendidikan jasmani.

\section{Pengaruh Motor Cognitive Coordination Training dalam Aktivitas Pendidikan Jasmani terhadap Gross Motor Skill}

Pengembangan keterampilan gerak (gross motor) harus dilakukan sejak usia dini. Hal ini diharapkan dapat dilakukan melalui berbagai upaya seperti aktivitas bermain, aktivitas pendidikan jasmani, dan aktivitas pembelajaran lain yang relevan. Dalam upaya memaksimalkan suatu aktivitas pembelajaran, para stakeholder dan guru pendidikan jasmani dalam rencana pelaksanan pembelajaran menggunakan bermacam-macam model pembelajaran, gaya mengajar, pendekatan cara mengajar, media sumber belajar. Di samping menggunakan rencana pelaksanaan pembelajaran tersebut, terdapat penambahan program motor cognitive coordination training dalam pembelajaran pendidikan jasmani di sekolah.

Program motor cognitive coordination training merangsang anak untuk bergerak dari stimulasi cognitive dengan variasi yang berbeda-beda dan tingkatan yang semakin komplek. Penambahan 
program motor cognitive coordination training menjadi pilihan peneliti karena diasumsikan akan memberikan pengaruh yang signifikan dalam menstimulasi perkembangan otot. Berdasarkan beberapa penelitian, motor cognitive coordination training berpengaruh terhadap aktivitas fisik (Guimarães, Pereira, Oliveira, Carvalho, \& Peixoto, 2018), penurunan fungsi fisik dan mental (Falbo, Condello, Capranica, Forte, \& Pesce, 2016), kesehatan dan memiliki kemampuan motorik yang baik (D. Niederer et al., 2019).

Keterampilan motorik kasar anak merupakan hal yang penting karena keterampilan ini merupakan dasar bagi anak untuk menguasai keterampilan yang lebih kompleks. Anak mempunyai keterampilan motorik kasar, maka anak tersebut akan lebih lincah dan serasi seperti saat berlari, melompat dengan dua kaki dan berjingkat (Seefeld \& Wasik, 2008).

Keterampilan motorik memiliki peranan penting dalam proses perkembangan anak terutama untuk menunjang aktivitas fisik yang dilakukan sehari-hari, di mana anak yang memiliki kemampuan koordinasi yang baik mampu melakukan keterampilan gerak yang lebih baik, dibandingkan dengan anak yang memiliki keterampilan gerak kurang baik (Bardid, Rudd, Lenoir, Polman, \& Anderson, 2015). Kemudian kemampuan koordinasi juga berpengaruh terhadap pola hidup anak-anak, di mana anak yang memiliki kemampuan koordinasi yang kurang baik cenderung memiliki masalah terhadap berat badan (Maia \& Stasinopoulos, 2015).

Berdasarkan uraian di atas, jelas menunjukkan bahwa gross motor anak berkaitan dengan gerakan fisik yang membutuhkan keseimbangan dan koordinasi antar anggota tubuh, dengan menggunakan otot-otot besar, sebagian atau seluruh anggota tubuh. Perkembangan motorik kasar anak pada permulaannya tergantung pada proses kematangan fisik dan saraf pada anak, yang selanjutnya kematangan tergantung dari belajar dan pengetahuan serta pengalaman. Sehingga diharapkan meningkatkan kualitas hidup anak itu sendiri dan lebih lanjutnya meningkatkan kualitas hidup di masa yang akan datang.

Dari hasil penelitian antara kelompok kontrol dan kelompok eksperimen hasilnya sama-sama memberikan peningkatan yang signifikan walaupun kelompok ekperimen sedikit lebih tinggi peningkatannya.

\section{Pengaruh Motor Cognitive Coordination Training dalam Aktivitas Pendidikan Jasmani terhadap Working Memory}

Berdasarkan hasil temuan penelitian sudah dapat simpulkan bahwa program latihan motor cognitive coordination training memiliki pengaruh yang sangat signifikan terhadap kapasitas working memory siswa sekolah dasar. Hal ini berdasarkan hasil penghitungan IMB SPSS statistics 20 pada tabel 9. Adanya beberapa penelitian terkait pemberian program latihan kognitif terhadap perkembangan kapasitas working memory. Sebuah penelitian menunjukan bahwa pemberian latihan dengan menambahkan tantangan kognitif memiliki dampak yang signifikan terhadap kemampuan pengambilan keputusan pada atlet sepak bola junior (Winkler, 2017). Kemudian dalam sebuah penelitian yang lain menunjukan bahwa terdapat peningkatan yang signifikan pada kapasitas working memory atlet, setelah diberikan program latihan dengan tugas kognitif pada atlet sepak bola (Alesi, Bianco, Luppina, \& Palma, 2016). Sedangkan sebuah penelitian yang lain, membandingkan program latihan, hasilnya adalah aktifitas gerak dengan tantangan kognisi lebih efektif untuk meningkatkan kemampuan memori (Kim, 2017). Berdasarkan uraian-uraian pada penelitian terdahulu dapat disimpulkan bahwa aktivitas jasmani dengan program latihan yang ditambahkan dengan tugas-tugas kognitif mampu meningkatkan kapasitas working memory, dan memiliki peranan yang sangat penting dalam kemampuan proses kognitif. Maka dari itu, program ini perlu dikembangkan lebih lanjut, agar dapat bermanfaat bagi perkembangan pendidikan, di mana terdapat tuntutan untuk pengembangan kognitif menjadi lebih baik.

\section{Pengaruh Aktivitas Pendidikan Jasmani terhadap Gross Motor Skill}

Pendidikan jasmani merupakan pendidikan yang melibatkan aktivitas fisik guna memperoleh kemampuan dan keterampilan jasmani. Pendidikan jasmani merupakan bagian yang tidak dapat dipisahkan dari kehidupan manusia, pendidikan jasmani membantu siswa untuk mengembangkan pengetahuan, sikap, keterampilan motorik dan perilaku yang diperlukan untuk mempertahankan gaya hidup aktif secara fisik (Grissom, 2005). Berdasarkan hasil pengolahan data, seperti yang tertera pada 
tabel 8, menunjukan hasil bahwa program pendidikan jasmani di sekolah dasar berpengaruh terhadap gross motor skill. Walaupun pada kenyataannya, pendidikan jasmani dan olahraga di sekolah, utamanya untuk pengembangan keterampilan fisik dan penyediaan aktivitas fisik pada anak-anak dan remaja (Sallis, McKenzie, Alcaraz, Kolody, \& Faucette, 1997). Keterampilan gerakan dasar, seperti yang dikembangkan dalam pendidikan jasmani dan olahraga, membentuk fondasi bagi hampir semua kegiatan olah raga dan fisik di kemudian hari (Gallahue, 1995). Pengembangan berbagai keterampilan gerakan dasar melalui program pendidikan jasmani dan olahraga adalah kondisi yang diperlukan untuk keunggulan dalam berolahraga (Abbott, Collins, Martindale, \& Sowerby, 2002).

Rink (2014) menyatakan bahwa pembelajaran dengan memberikan pengalaman harus memiliki potensi untuk meningkatkan kinerja motorik anak, dan keterampilan aktivitas siswa. Perkembangan motorik kasar dipengaruhi oleh kegiatan pendidikan jasmani reguler, serta dilayani oleh guru kelas reguler. Dengan cara ini, praktik terstruktur dan instruksi yang sesuai dapat diberikan oleh guru dengan latar belakang pendidikan jasmani menjadi sangat penting dalam mempromosikan pengembangan motorik kasar pada anak (Lemos, Avigo, \& Barela, 2012).

\section{Pengaruh Aktivitas Pendidikan Jasmani Terhadap Working Memory}

Pendidikan jasmani (Penjas) merupakan pendidikan yang dapat mendukung pencapaian tujuan pendidikan secara keseluruhan. Beberapa penelitian telah dilakukan sebelumnya untuk menilai hubungan antara aktivitas fisik dan kinerja akademik. Pendidikan jasmani dan olahraga telah mendaftarkan banyak manfaat yang terkait dengan partisipasi dalam kegiatan ini, yaitu membantu anak-anak mengembangkan rasa memiliki dan menjaga tubuh-tubuh mereka sendiri serta orang lain. Berkontribusi terhadap pengembangan pikiran dan tubuh yang terintegrasi, mengembangkan pemahaman tentang peran aktivitas fisik aerobik dan anaerobik dalam kesehatan, secara positif meningkatkan kepercayaan diri dan pengembangan harga diri. Terakhir, meningkatkan perkembangan sosial dan kognitif serta prestasi akademik (Talbot, 2001). Para peneliti telah menyarankan bahwa pendidikan jasmani dan olahraga dapat meningkatkan kinerja akademik dengan meningkatkan aliran darah ke otak, meningkatkan suasana hati, meningkatkan kewaspadaan mental, dan meningkatkan harga diri (Hills A, 1998).

Berdasarkan penelitian-penelitian sebelumnya telah menunjukkan bahwa intervensi aktivitas fisik pada masa kanak-kanak memberikan hubungan positif terhadap working memory. Misalnya, anak-anak yang terlibat dalam program pelatihan fisik selama 8 minggu (Hsieh, Lin, Chang, Huang, \& Hung, 2017), 10 minggu (Koutsandréou, Wegner, Niemann, \& Budde, 2016), atau 9 bulan (Kamijo et al., 2011). Sebagaimana diyakini bahwa manfaat olahraga tidak hanya fisik tetapi juga menyatukan koneksi dalam otak untuk merangsang jalur baru, yang mau tidak mau mempercepat proses pembelajaran (Spark, 2008).

\section{Perbedaan Pengaruh antara Program Motor Cognitive Coordination Training dalam Aktivitas Pendidikan Jasmani dan Program Aktivitas Pendidikan Jasmani terhadap Gross Motor Skill dan working memory di Sekolah Dasar}

Hasil studi-studi penelitian tentang program motor cognitive coordination training dalam aktivitas pendidikan jasmani dan program aktivitas pendidikan jasmani, menyampaikan kesimpulan bahwa individu yang berpartisipasi dalam aktivitas fisik dan melakuan pengembangan pada tugas kognitif menunjukkan kinerja yang unggul pada tugas fungsi eksekutif dibandingkan dengan individu yang berpartisipasi dalam olahraga tanpa tugas kognitif di dalamnya. Miyake et al., (2000) menyampaikan bahwa memori kerja tidak hanya merupakan subkomponen dari salah satu dari tiga aspek utama fungsi eksekutif, tetapi juga berbagi peran yang sama dan menonjol dalam aspek lain dari fungsi eksekutif.

Studi intervensi sebelumnya telah melaporkan bahwa efek positif dari aktivitas fisik pada masa kanak-kanak khususnya korelasi perilaku memori kerja, dengan anak-anak yang lebih aktif menunjukkan kinerja tugas yang lebih baik dalam bentuk waktu reaksi yang lebih pendek (Hsieh et al., 2017) atau akurasi respon yang lebih tinggi (Kamijo et al., 2011). Integrasi pada motor cognitive coordination traning (MCCT) yaitu dengan menggabungkan tugas gerak motorik dengan tugas yang bersifat kognitif (variasi stimulasi kognitif). Misalnya dengan menambahkan angka, warna, nama hewan dan lain-lainnya, mungkin kegiatan tersebut juga berguna dalam memberikan wawasan lebih 
lanjut tentang bagaimana memori kerja dikaitkan dengan aktifitas fisik pada masa kanak-kanak. Program spesifik motor cognitive coordination traning yang berkaitan dengan klasifikasi stimulasi dan pemilihan respons tahap akhir harus memberikan wawasan tentang dinamika temporal working memory, dan bagaimana proses tersebut dikaitkan dengan aktifitas fisik.

Perlu dicatat bahwa kebugaran motorik dapat dipengaruhi oleh jenis olahraga yang dilakukan. Anak-anak yang berpartisipasi dalam aktivitas motorik yang kompleks, seperti permainan bola yang menuntut secara kognitif membutuhkan koordinasi tangan-mata, keseimbangan, dan kontrol objek, menunjukkan peningkatan yang jauh lebih besar (Hsieh et al., 2017; Koutsandréou et al., 2016) daripada mereka yang terlibat dalam latihan yang lebih sederhana (misalnya berlari, bersepeda). Oleh karena itu, anak-anak yang terlibat dalam jumlah aktifitas fisik yang sama dapat mengembangkan berbagai tingkat kebugaran motorik.

Selain itu juga, karena motor cognitive coordination traning merupakan latihan yang berdasar dari program latihan life kinetic, yaitu program pelatihan dengan desain tugas gerakan multi-tasking, melibatkan seluruh bagian dari tubuh dan merangsang kerjasama setiap bagian otak. Selain itu gerakan-gerakan dalam life kinetik dapat merangsang sel otak untuk menciptakan percabangan yang baru bahkan membentuk sel otak (neuron) yang baru yang disebabkan oleh rangsangan otak terhadap tugas gerakan yang baru (Lutz, 2017). Karena stimulasi (tugas kognisi bervariasi) untuk gerak membuat anak ingin mencoba dan mencoba sehingga repetisi anak untuk melakukan tugas gerak lebih banyak.

\section{PENUTUP}

Berdasarkan hasil temuan dan pembahasan, dapat disimpulkan pertama, terdapat pengaruh motor cognitive coordination training terhadap peningkatan gross motor skill dan working memory siswa dalam pendidikan jasmani di sekolah dasar. Kedua, terdapat pengaruh program aktivitas pendidikan jasmani terhadap peningkatan gross motor skill dan working memory siswa di sekolah dasar. Ketiga aktivitas pendidikan jasmani akan lebih memberikan pengaruh positif terhadap gross motor skill dan working memory di sekolah dasar jika dalam proses aktivitas jasmani ada penambahan program motor cognitive coordination training. Program motor cognitive coordination training yang diterapkan dalam aktivitas pendidikan jasmani, merupakan salah satu program yang dapat membantu stakeholder dan para guru dalam mengoptimalkan kemampuan siswa. Program latihan yang menggabungkan tugas gerak motorik dan tugas yang bersifat kognitif merupakan gerakan yang dapat merangsang seluruh bagian otak secara bersamaan dan merangsang kerjasama setiap bagian otak. Selain itu dapat merangsang sel otak untuk dapat menciptakan percabangan yang baru yang disebabkan oleh rangsangan otak terhadap tugas gerakan yang baru, sehingga memberikan dampak positif bagi pengembangan anak.

\section{UCAPAN TERIMA KASIH}

Peneliti ingin menyampaikan rasa terimakasih kepada Kepala Sekolah,Guru dan peserta didik SD Negeri Leles III dan SDNegeri Leles I.

\section{DAFTAR PUSTAKA}

Abbott, A., Collins, D., Martindale, R. J. J., \& Sowerby, K. (2002). Talent identification and development: an academic review. Sport University of Edinburgh, (August), 103. Retrieved from http://researchrepository.napier.ac.uk/2493/.

Adams, E. J., Nguyen, A. T., \& Cowan, N. (2018). Theories of working memory: Differences in definition, degree of modularity, role of attention, and purpose. Language, Speech, and Hearing Services in Schools, 49(3), 340-355. https://doi.org/10.1044/2018_lshss-17-0114.

Alesi, M., Bianco, A., Luppina, G., \& Palma, A. (2016). Improving children's coordinative skills and executive functions: The effects of a football exercise program. https://doi.org/10.1177/0031512515627527.

Baddeley, A. (2003). Working memory and language: An overview. Journal of Communication Disorders, 36(3), 189-208. https://doi.org/10.1016/S0021-9924(03)00019-4. 
Jurnal Penelitian Ilmu Pendidikan, 13 (2), 2020 - 106

Setiawan, Hendrayana \& Mahendra

Bardid, F., Rudd, J. R., Lenoir, M., Polman, R., \& Anderson, D. I. (2015). Cross-cultural comparison of motor competence in children from Australia and Belgium, 6(July), 1-8. https://doi.org/10.3389/fpsyg.2015.00964.

Bherer, L., Peterson, M. S., Kramer, A. F., Colcombe, S., Erickson, K., \& Becic, E. (2005). Training effects on dual-task performance: Are there age-related differences in plasticity of attentional control? Psychology and Aging, 20(4), 695-709. https://doi.org/10.1037/0882-7974.20.4.695.

Boddy, L. M., Hackett, A. F., \& Stratton, G. (2009). Changes in BMI and prevalence of obesity and overweight in children in Liverpool, 1998-2006. Perspectives in Public Health, 129(3), 127-131. https://doi.org/10.1177/1757913908094808.

Boron, J. B., Turiano, N. A., Willis, S. L., \& Schaie, K. W. (2007). Effects of cognitive training on change in accuracy in inductive reasoning ability. The Journal of Gerontology: Series B, 62(3), P179-P186. https://doi.org/10.1093/geronb/62.3.P179.

Brehmer, Y., Westerberg, H., \& Bäckman, L. (2012). Working-memory training in younger and older adults: Training gains, transfer, and maintenance. Human Neuroscience, 6(March), 1-7. https://doi.org/10.3389/fnhum.2012.00063

Cowan, N. (2016). Working memory maturation: Can we get at the essence of cognitive growth? $\begin{array}{llll}\text { Perspectives on } \quad \text { Psychological } & \text { Science, } & \text { 11(2), }\end{array}$ https://doi.org/10.1177/1745691615621279.

Edwards, J. D., Wadley, V. G., Vance, D. E., Wood, K., \& Roenker, D. L. (2005). The impact of speed of processing training on cognitive and everyday performance. Aging \& Mental Health. 9(3), 262-271. https://doi.org/10.1080/13607860412331336788.

Elferink-gemser, M. T., Smith, J., \& Visscher, C. (2014). The relationship between motor skills and cognitive skills in 4-16 year old typically developing children: A systematic review. Journal of Science and Medicine in Sport, 9. https://doi.org/10.1016/j.jsams.2014.09.007.

Fairclough, S. J., Boddy, L. M., Hackett, A. F., \& Stratton, G. (2009). Associations between children's socioeconomic status, weight status, and sex, with screen-based sedentary behaviours and sport participation. International Journal of Pediatric Obesity, 4(4), 299-305. https://doi.org/10.3109/17477160902811215.

Falbo, S., Condello, G., Capranica, L., Forte, R., \& Pesce, C. (2016). Effects of physical-cognitive dual task training on executive function and gait performance in older adults: A randomized controlled trial. BioMed Research International, 2016. https://doi.org/10.1155/2016/5812092.

Fraenkel, J., Wallen, N., \& Hyun, H. (2011). How to design and evaluate research in education. New York: McGraw-Hill.

Fritz, N. E., Cheek, F. M., \& Nichols-Larsen, D. S. (2015). Motor-cognitive dual-task training in persons with neurologic disorders: A systematic review. Journal of Neurologic Physical Therapy, 39(3), 142-153. https://doi.org/10.1097/NPT.0000000000000090.

Gallahue, D. L. (1995). Developmental Physical Education for Today's School Children-Brown \& Benchmark. Madison: Brown \& Benchmark Pub.

Grissom, J. B. (2005). Physical fitness and academic achievement. Journal of Exercise Physiology, 8(1), 11-25. https://doi.org/10.1519/JSC.0b013e3181874564.

Guimarães, V., Pereira, A., Oliveira, E., Carvalho, A., \& Peixoto, R. (2018). Design and evaluation of an exergame for motor-cognitive training and fall prevention in older adults. ACM International Conference Proceeding Series, 202-207. https://doi.org/10.1145/3284869.3284918.

Herold, F., Hamacher, D., Schega, L., \& Müller, N. G. (2018). Thinking while moving or moving while thinking - concepts of motor-cognitive training for cognitive performance enhancement. Frontiers in Aging Neuroscience, 10(AUG), 1-11. https://doi.org/10.3389/fnagi.2018.00228.

Hills A. (1998). Scholastic and intellectual development and sport. In: Chan K-M, Micheli L, eds. Sports and Children. Champaign, Ill: Human Kinetics; 76-90.

Hsieh, S. S., Lin, C. C., Chang, Y. K., Huang, C. J., \& Hung, T. M. (2017). Effects of childhood gymnastics program on spatial working memory. Medicine and Science in Sports and Exercise, 49(12), 2537-2547. https://doi.org/10.1249/MSS.0000000000001399.

Hurlock, E. (1998). Child development: An introduction. In Annual review of neuroscience, 34.

Jaakkola, T., Hillman, C., Kalaja, S., \& Liukkonen, J. (2015). The associations among fundamental movement skills, self-reported physical activity and academic performance during junior high school in Finland. Journal of Sports Sciences, 33(16), 1719-1729. 
https://doi.org/10.1080/02640414.2015.1004640.

James F Sallis, Thomas L McKenzie, John E. Alcaraz, Bohdan Kolody, Nell Faucette, \& M. E. H. (1997). The effects of a 2-year physical education program (SPARK) on physical activity and fitness in elementary school students. Physics Letters. Section B, 245(8), 348-354. https://doi.org/https://dx.doi.org/10.2105\%2Fajph.87.8.1328.

Johann, V. E., Stenger, K., Kersten, S., \& Karbach, J. (2016). Effects of motor-cognitive coordination training and cardiovascular training on motor coordination and cognitive functions. Psychology of Sport and Exercise, 24, 118-127. https://doi.org/10.1016/j.psychsport.2016.01.008.

Kamijo, K., Pontifex, M. B., O’Leary, K. C., Scudder, M. R., Wu, C. T., Castelli, D. M., \& Hillman, C. H. (2011). The effects of an afterschool physical activity program on working memory in preadolescent children. Developmental Science, 14(5), 1046-1058. https://doi.org/10.1111/j.1467-7687.2011.01054.x.

Kane, M. J., Hambrick, D. Z., Tuholski, S. W., Wilhelm, O., Payne, T. W., \& Engle, R. W. (2004). The generality of working memory capacity: A latent-variable approach to verbal and visuospatial memory span and reasoning. 133(2), 189-217. https://doi.org/10.1037/00963445.133.2.189.

Kim, S. (2017). Effect of motor cognition program for improving temporal-spatial timing memory ability with mild cognitive impairment patients. Journal of Exercise Rehabilitation, 13(4), 430435. https://doi.org/10.12965/jer.1735086.543.

Koutsandréou, F., Wegner, M., Niemann, C., \& Budde, H. (2016). Effects of motor versus cardiovascular exercise training on children's working memory. Medicine and Science in Sports and Exercise, 48(6), 1144-1152. https://doi.org/10.1249/MSS.0000000000000869.

Lauenroth, A., Ioannidis, A. E., \& Teichmann, B. (2016). Influence of combined physical and cognitive training on cognition: a systematic review. BMC Geriatrics, 21-23. https://doi.org/10.1186/s12877-016-0315-1.

Lemos, A. G., Avigo, E. L., \& Barela, J. A. (2012). Physical education in kindergarten promotes fundamental motor skill development. Advances in Physical Education, 02(01), 17-21. https://doi.org/10.4236/ape.2012.21003.

Lutz, H. (2017). Life Kinetik®. Meyer \& Meyer.

Luz, C., Rodrigues, L. P., \& Cordovil, R. (2015). The relationship between motor coordination and executive function in 4th grade children. European Journal of Developmental Psychology, 12(2), 129-141. Https://doi.org/10.1080/17405629.2014.966073.

Maia, A., \& Stasinopoulos, M. D. (2015). Gross Motor Coordination and Weight Status of Portuguese Children Aged 6 - 14 Years. OO(September 2014). https://doi.org/10.1002/ajhb.22715.

Mavilidi, M. F., Okely, A., Chandler, P., Louise Domazet, S., \& Paas, F. (2018). Immediate and delayed effects of integrating physical activity into preschool children's learning of numeracy skills. Journal of Experimental Child Psychology, 166, 502-519. https://doi.org/10.1016/j.jecp.2017.09.009.

Miyake, A., Friedman, N. P., Emerson, M. J., Witzki, A. H., Howerter, A., \& Wager, T. D. (2000). The unity and diversity of executive functions and their contributions to complex "frontal lobe" tasks: A latent variable analysis. Cognitive Psychology, 41(1), 49-100. https://doi.org/10.1006/cogp.1999.0734.

Niederer, D., Plaumann, U., Seitz, T., Wallner, F., Wilke, J., Engeroff, T., ... Banzer, W. (2019). How does a 4-week motor-cognitive training affect choice reaction, dynamic balance and cognitive performance ability? A randomized controlled trial in well-trained, young, healthy participants. SAGE Open Medicine, 7, 205031211987002. https://doi.org/10.1177/2050312119870020.

Niederer, I., Kriemler, S., Gut, J., Hartmann, T., Schindler, C., Barral, J., \& Puder, J. J. (2011). Relationship of aerobic fitness and motor skills with memory and attention in preschoolers (Ballabeina): A cross-sectional and longitudinal study. BMC Pediatrics, 11. https://doi.org/10.1186/1471-2431-11-34.

O' Brien, W., Belton, S., \& Issartel, J. (2016). The relationship between adolescents' physical activity, fundamental movement skills and weight status. Journal of Sports Sciences, 34(12), 1159-1167. https://doi.org/10.1080/02640414.2015.1096017.

Parisi, J. M., Rebok, G. W., Xue, Q. L., Fried, L. P., Seeman, T. E., Tanner, E. K., .. Carlson, M. C. (2012). The role of education and intellectual activity on cognition. Journal of Aging Research, 
Jurnal Penelitian Ilmu Pendidikan, 13 (2), 2020 - 108

Setiawan, Hendrayana \& Mahendra

2012, 20-24. https://doi.org/10.1155/2012/416132.

Pietsch, S., Böttcher, C., \& Jansen, P. (2017). Cognitive motor coordination training improves mental rotation performance in primary school-aged children. Mind, Brain, and Education, 11(4), 176180. https://doi.org/10.1111/mbe.12154.

Plummer, P., \& Eskes, G. (2015). Measuring treatment effects on dual-task performance: A framework for research and clinical practice. Frontiers in Human Neuroscience, 9(APR), 1-7. https://doi.org/10.3389/fnhum.2015.00225.

Ratey, J. J., \& Loehr, J. E. (2011). The positive impact of physical activity on cognition during adulthood: A review of underlying mechanisms, evidence and recommendations. Reviews in the Neurosciences, 22(2), 171-185. https://doi.org/10.1515/RNS.2011.017.

Rebok, G. W., Carlson, M. C., \& Langbaum, J. B. S. (2007). Training and maintaining memory abilities in healthy older adults: Traditional and novel approaches. Journals of Gerontology Series B Psychological Sciences and Social Sciences, 62(1), 53-61. https://doi.org/10.1093/geronb/62.special_issue_1.53.

Rink, J. E. (2014). Teaching physical education for learning. New York: McGraw-Hill.

Rintala, A. (2017). Reliability assessment of scores from video-recorded TGMD-3 performances. Journal of Motor Learning and Development, 5(1), 59-68. https://doi.org/10.1123/jmld.20160007.

Robinson, L. E., Stodden, D. F., Barnett, L. M., Lopes, V. P., Logan, S. W., Rodrigues, L. P., \& D'Hondt, E. (2015). Motor competence and its effect on positive developmental trajectories of health. Sports Medicine, 45(9), 1273-1284. https://doi.org/10.1007/s40279-015-0351-6.

Roenker, D. L., Cissell, G. M., Green, B., Ball, K. K., Wadley, V. G., \& Edwards, J. D. (2003). Speedof-processing and driving simulator training result in improved driving performance, 45(2), 218-233.

Seefeldt, C. \& Barbara, A. W. (2008). Early education: Three-, four-, and five-year-olds go to school, (terj. Pius Nasar, pendidikan anak usia dini menyiapkan anak usia tiga, empat, dan lima tahun masuk sekolah). Jakarta: Indeks.

Simons, J., \& Eyitayo, G. B. (2016). Aspects of reliability and validity of the TGMD-3 in 7-10 year old children with intellectual disability in Belgium. European Psychometricity Journal, 8(1), 316.

Slavin, K. V. (2013). Stimulation of the peripheral nervous system. Soins; la revue de reference infirmiere, 29.

Smith, J., Li, S., Schmiedek, F., Huxhold, O., \& Ro, C. (2008). Working memory plasticity in old age: Practice gain, transfer, and maintenance. Psychology and Aging, 23(4), 731-742. https://doi.org/10.1037/a0014343.

Spark RJ. (2008). The revolutionary new science of exercise and the brain. New York, NY: Little, Brown and Company.

Stodden, D. F., Goodway, J. D., Langendorfer, S. J., Roberton, M. A., Rudisill, M. E., Garcia, C., \& Garcia, L. E. (2008). A developmental perspective on the role of motor skill competence in physic...: EBSCOhost. Quest, (May 2013), 290-306. Retrieved from http://web.a.ebscohost.com.apollo.worc.ac.uk/ehost/pdfviewer/pdfviewer?vid=4\&sid=3691 cf5735ce-47c0-8601-d42fdf27c2b7\%40sdc-v-sessmgr06.

Stratton, G., Canoy, D., Boddy, L. M., Taylor, S. R., Hackett, A. F., \& Buchan, I. E. (2007). Cardiorespiratory fitness and body mass index of 9-11-year-old English children: A serial crosssectional study from 1998 to 2004. International Journal of Obesity, 31(7), 1172-1178. https://doi.org/10.1038/sj.ijo.0803562.

Talbot M. (2001). The case for physical education. In: Doll-Tepper G, Scoretz D, eds. World Summit on Physical Education. Berlin, Germany: ICSSPE; 39-50.

Veldman, S. L. C., Jones, R. A., \& Okely, A. D. (2016). Efficacy of gross motor skill interventions in young children: an updated systematic review. BMJ Open Sport \& Exercise Medicine, 2(1), e000067. https://doi.org/10.1136/bmjsem-2015-000067.

Verhaeghen, P., Marcoen, A., \& Goossens, L. (1992). Improving memory performance in the aged through mnemonic training: A meta-analytic study. Psychol Aging, 7(2), 242-251. DOI: 10.1037//0882-7974.7.2.242.

Vlahov, E., Baghurst, T. M., \& Mwavita, M. (2014). Preschool motor development predicting high 
Jurnal Penelitian Ilmu Pendidikan, 13 (2), 2020 - 109

Setiawan, Hendrayana \& Mahendra

school health-related physical fitness: A prospective study. Perceptual and Motor Skills, 119(1), 279-291. https://doi.org/10.2466/10.25.pms.119c16z8.

Williams, B. L., Temple, V. A., Bell, R. I., Greyling, L., Naylor, P. J., LeGear, M., \& Sloan, E. (2012). A window of opportunity? Motor skills and perceptions of competence of children in kindergarten. International Journal of Behavioral Nutrition and Physical Activity, 9(1), 29. https://doi.org/10.1186/1479-5868-9-29.

Winkler, W. (2017). Motor skills and cognitive training for junior soccer players. International Journal of Performance Analysis in Sport, 1(1), 91-105.

https://doi.org/10.1080/24748668.2001.11868252. 